\title{
The acyclic nucleoside phosphonate analogues, adefovir, tenofovir and PMEDAP, efficiently eliminate banana streak virus from banana (Musa spp.)
}

\author{
B. Helliot ${ }^{\text {a }}$, B. Panis ${ }^{\text {b }}$, E. Frison ${ }^{\text {c }}$, E. De Clercq ${ }^{\text {d }}$, R. Swennen ${ }^{\text {b }}$, P. Lepoivre ${ }^{\text {a }}$, J. Neyts ${ }^{\text {d,* }}$ \\ a Plant Pathology Unit, Gembloux Agricultural University, 5030 Gembloux, Belgium \\ ${ }^{\mathrm{b}}$ Laboratory of Tropical Crop Improvement, K.U. Leuven, 3001 Heverlee, Belgium \\ ${ }^{\mathrm{c}}$ INIBAP/IPGRI (International Network for the Improvement of Banana and Plantain/International \\ Plant Genetic Resources Institute), 34397 Montpellier, France \\ ${ }^{\mathrm{d}}$ Rega Institute for Medical Research, K.U. Leuven, 3000 Leuven, Belgium \\ Received 4 December 2002; accepted 13 March 2003
}

\begin{abstract}
We report that the anti-retroviral and anti-hepadnavirus molecules, adefovir, tenofovir and 9-(2-phosphonomethoxyethyl)-2,6-diaminopurine (PMEDAP), efficiently eradicate the episomal form of Banana streak virus (BSV) from banana plants. Up to $90 \%$ of plants regenerated from BSV-infected highly proliferating meristems were virus free following a 6-month treatment period with $10 \mu \mathrm{g} / \mathrm{ml}(\mathrm{a}$ non-phytotoxic concentration) of either compounds.
\end{abstract}

(C) 2003 Elsevier Science B.V. All rights reserved.

Keywords: Adefovir; Tenofovir; Badnavirus; Pararetrovirus; Banana streak virus; Chemotherapy; Hepadnavirus; Virus eradication

\section{Introduction}

Bananas, belonging to the Musa genus, are cultivated in about 120 tropical and subtropical countries. They provide staple food for millions of people (Frison and Sharrock, 1999). Bananas are threatened by different pathogens among which are viruses, such as the Banana streak virus (BSV). Banana streak was described for the first time as "la Mosaïque à Tirets" on the cultivar "Poyo" (AAA, Cavendish subgroup) by Lassoudière (1974) and similar disease symptoms were observed in Morocco on "Dwarf-Cavendish" (AAA, Cavendish subgroup) plants. The causal agent was then identified by Lockhart (1986). BSV presents a high degree of heterogeneity among isolates (Lockhart and Olszewski, 1993). It is a member of the badnavirus group (Lockhart, 1990) together with Rice tungro bacilliform virus (Hay et al., 1991), Commelina yellow mottle virus (Medberry et al., 1990), Sugarcane bacilliform virus (Bouhida et al., 1993) and Cacao swollen shoot virus (Hagen et al., 1993). This non-enveloped virus contains a

\footnotetext{
* Corresponding author.

E-mail address: johan.neyts@kuleuven.ac.be (J. Neyts).
}

circular dsDNA genome of $7.4 \mathrm{~kb}$ (Harper and Hull, 1998). Badnaviruses belong together with the caulimoviruses to the Pararetroviridae (Lockhart and Jones, 2000). The economic importance of this virus, transmitted by mealybugs, is explained not only by the direct effect of the disease on crop yield, but also by restrictions imposed on the deployment of improved hybrids because of the occurrence of the causal agent in many genotypes. LaFleur et al. (1996) detected by PCR that BSV genomic sequences can be integrated into genomic DNA of Musa. Meanwhile Harper et al. (1999) and Ndowora et al. (1999) suggested that this integrated sequence can lead to episomal forms. Strong evidence exists that integrated sequences that can be activated are associated with the B-genome of cultivated Musa, whereas Musa AAA group (cv. Williams) contains a dead (not activable) virus integrant (Geering et al., 2001). So far, reports on BSV elimination from infected banana plants are very scarce. We reported recently on the successful eradication of BSV from banana (cv. Williams BSJ, ITC.0579, AAA, Cavendish subgroup) through cryopreservation (Helliot et al., 2002, 2003). Because of the similarity in replication cycle between badnaviruses and hepadnaviruses, we wanted to determine whether selective inhibitors of HBV replication would be able to arrest the replication of badnaviruses and/or to 
eradicate the virus from banana plants. We therefore studied the effect of two well-known inhibitors of HBV replication, i.e. 9-(2-phosphonylmethoxyethyl)adenine (PMEA, adefovir) and 9-(2-phosphonylmethoxypropyl)adenine (PMPA, tenofovir) (Heijtink et al., 1993; Ying et al., 2000a,b) on BSV replication. Adefovir dipivoxil (Hepsera ${ }^{\mathrm{TM}}$ ), the oral prodrug of adefovir, has recently been approved in the USA and Europe for the treatment of chronic infections with HBV. Besides being active against hepadnaviruses, adefovir is also endowed with activity against retroviruses and herpesviruses (Naesens et al., 1997). PMEDAP, the 2,6-diaminopurine analogue of adefovir, has an activity spectrum similar to that of adefovir, but has not been developed for clinical use. Tenofovir is a potent inhibitor of the replication of hepadnaviruses and retroviruses, but has, unlike adefovir and PMEDAP, no activity against DNA viruses other than hepadnaviruses (Balzarini et al., 1993). The oral prodrug of PMPA (tenofovir disoproxil fumarate, Viread ${ }^{\mathrm{TM}}$ ) has been approved both in the US and Europe for the treatment of HIV infections.

Phytotoxic effects of tenofovir (PMPA), adefovir (PMEA) and PMEDAP (for structural formulae see Fig. 1) were monitored in two independent experiments on meristems excised from BSV-infected dessert banana plants belonging to the cultivar Williams BSJ (ITC.0579, AAA, Cavendish subgroup, Daniells et al., 2001). Compounds were kindly provided by Dr. N. Bischofberger (Gilead, Foster City, CA). Cultures were performed on semi-solid MS medium (Murashige and Skoog, 1962) supplemented with $1 \mu \mathrm{M}$ $N^{6}$-benzyladenine (BA), $1 \mu \mathrm{M}$ indole-3-acetic acid (IAA) and with either $0,10,25,50,100$ or $200 \mu \mathrm{g} / \mathrm{ml}$ of the respective antiviral agents and monthly refreshed. Following treatment for three consecutive months, plantlets were transferred to regular MS medium for regeneration. Plants grown on regular MS medium were used as control. The phytotoxic effect was evaluated based on the plant size and the percent survival. At a concentration of $10 \mu \mathrm{g} / \mathrm{ml}$ adefovir or PMEDAP, plantlet survival was respectively 92 and 100\% and plant size unaffected (Fig. 2). Tenofovir at $10 \mu \mathrm{g} / \mathrm{ml}$ had a more pronounced inhibitory effect on the growth of plantlets than adefovir or PMEDAP, but did not reduce survival. At $50 \mu \mathrm{g} / \mathrm{ml}$, tenofovir proved lethal to banana meristem development, whereas adefovir and PMEDAP exhibited a reduced regeneration (58 and $40 \%$ of the untreated plants, respectively) (Fig. 2). At 100 and $200 \mu \mathrm{g} / \mathrm{ml}$, all three compounds displayed significant toxic effects (data not shown).<smiles>Nc1ncnc2c1ncn2CCOCP(=O)(O)O</smiles>

\section{PMEA, Adefovir}<smiles>C[C@@H](Cn1cnc2c(N)ncnc21)OCP(=O)(O)O</smiles>

PMPA, Tenofovir<smiles></smiles>

PMEDAP

Fig. 1. Structural formulae of PMPA (tenofovir), PMEA (adefovir) and PMEDAP. 

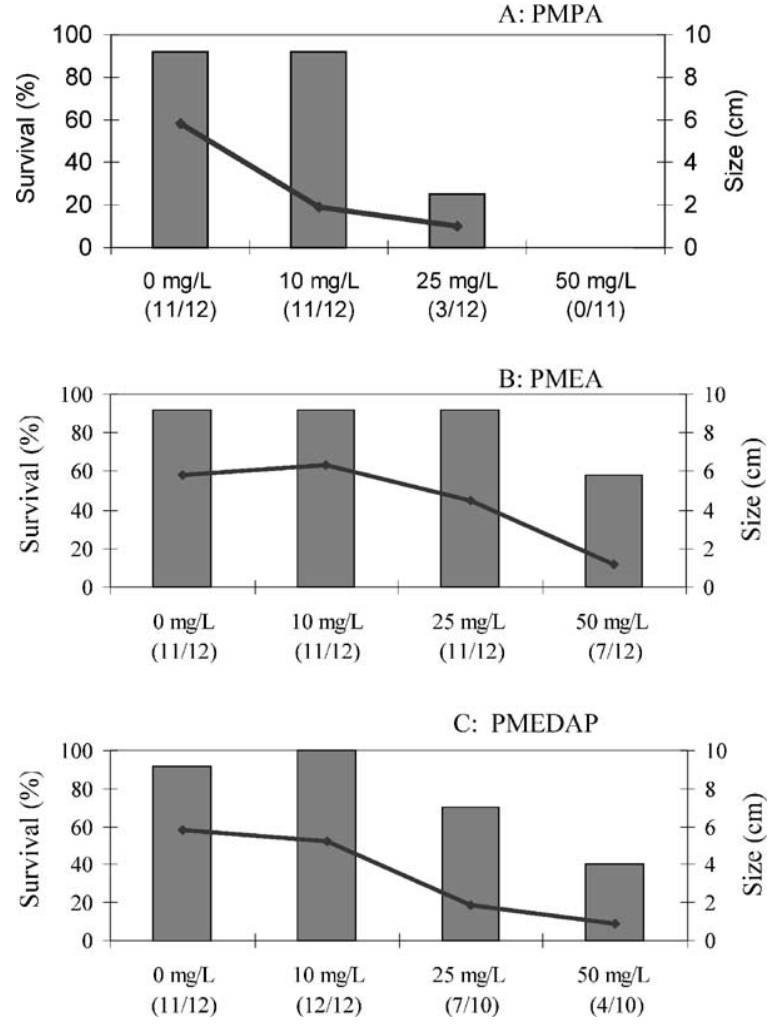

Fig. 2. Phytotoxicity assay performed on meristems excised from in vitro banana plants (cv. Williams BSJ, ITC.0579, AAA) and treated for 3 months with (A) tenofovir (PMPA), (B) adefovir (PMEA) or (C) PMEDAP. Bars indicate the percentage survival and the line the effect of the antiviral compounds on the plantlet size at the end of the 3-month treatment period. Data are mean values for two independent experiments.

Highly proliferating meristems (Panis et al., 1996) were chopped, mixed and transferred for either 2, 4 or 6 months on MS medium supplemented with $1 \mu \mathrm{M}$ BA, $1 \mu \mathrm{M}$ IAA and with $10 \mu \mathrm{g} / \mathrm{ml}$ of either tenofovir, adefovir or PMEDAP. The plantlets were subcultured every month in fresh medium. Following this treatment period, material was transferred to fresh regeneration MS medium supplemented with $1 \mu \mathrm{M}$ BA and $1 \mu \mathrm{M}$ IAA. The health status of the regenerated material was initially checked on in vitro plants by TAS-ELISA (Ndowora and Lockhart, 2000). Tissue samples were extracted and diluted in phosphate-buffered saline, $\mathrm{pH} 7.4$, containing $0.05 \%(\mathrm{v} / \mathrm{v})$ Tween 20 and $2 \%$ PVP. A rabbit polyclonal antiserum was used as primary antibody, a chicken antiserum as second antibody and an anti-chicken conjugate (Rabbit anti-chicken; Sigma) as the third antibody. The cut-off value for the threshold was 0.2 absorbance units. The putative virus-free material was tested a second time as part of an internationally accepted practice (Diekmann and Putter, 1996) after a greenhouse acclimatisation phase of 6 months. The eradication rate (ER) observed in fine for each treatment was calculated as follows:

First ELISA test performed on in vitro plants:

$\mathrm{ER}=\left(\frac{\text { negative in vitro plants }}{\text { tested in vitro plants }}\right) \times 100$
Second ELISA test performed on in vivo plants:

$$
\begin{aligned}
\mathrm{ER}= & \left(\frac{\text { negative in vitro plants }}{\text { tested in vitro plants }}\right) \\
& \times\left(\frac{\text { negative in vivo plants }}{\text { tested in vivo plants }}\right) \times 100
\end{aligned}
$$

The percentage of in vivo regenerated plants from clumps treated with tenofovir that proved to be virus free was the highest $(90 \%)$ following a 6-month incubation period with the drug and decreased somewhat with shorter incubation periods (Fig. 3A). Adefovir proved about as efficient as tenofovir in eradicating the virus and resulted in $88 \%$ of healthy plants following a 6-month treatment period (Fig. 3B). PMEDAP proved somewhat less efficient in eradicating the virus than adefovir; $69 \%$ of the regenerated plants were BSV free following a 4- or 6-month-treatment period (Fig. 3C). In comparison, only $15 \%$ of control plants were virus free (Fig. 3A-C). Such "spontaneous" virus eradication, after an in vitro culture phase, is a widespread phenomenon, and can be attributed to the uneven distribution of viral particles in the meristems (our unpublished data).

A concern may be that the antibody used (Geering et al., 2001) would not recognise all viral variants. We therefore employed an ImmunoCapture-Polymerase Chain Reaction-Enzyme Linked OligonucleotideSorbent Assay (IC-PCR-ELOSA) protocol (Delanoy et al., 2001) (amplifying a fragment in the aspartic protease/reverse transcriptase gene junction) to further confirm the data collected by the ELISA method. Twenty at random selected drug-treated plants that proved negative in the ELISA also proved negative in the PCR assay at the end of the experiment (data not shown). This thus corroborates the observed antiviral effect as detected by means of the ELISA method and also excludes the possibility that the ELISA would have missed some variants of the virus. It is in international practice generally accepted that virus-indexing results remain constant afterwards (Diekmann and Putter, 1996).

Badnaviruses are believed to have a replication cycle that closely resembles that of hepadnaviruses. Adefovir and PMEDAP have the ability to inhibit, as their $5^{\prime}$-diphosphorylated metabolites (i.e. PMEApp and PMEDAPpp), both viral DNA polymerases and reverse transcriptases (Naesens et al., 1997). Hence, these compounds are selective inhibitors of the replication of DNA viruses such as herpesviruses, hepadnaviruses such as HBV and retroviruses such as HIV (Naesens et al., 1997). However, tenofovir, as its $5^{\prime}$-diphosphorylated metabolite (PMPApp), solely inhibits the replication of viruses where a reverse transcriptase is involved in the replication cycle (hepadnaviruses and retroviruses). Accordingly, PMPApp is a potent inhibitor of the reverse transcriptase activity but not of DNA polymerases (Naesens et al., 1997). The mechanism of the selective antiviral activity of tenofovir, adefovir and PMEDAP on badnavirus replication can thus most likely be ascribed to an inhibition of the reverse transcriptase activity 


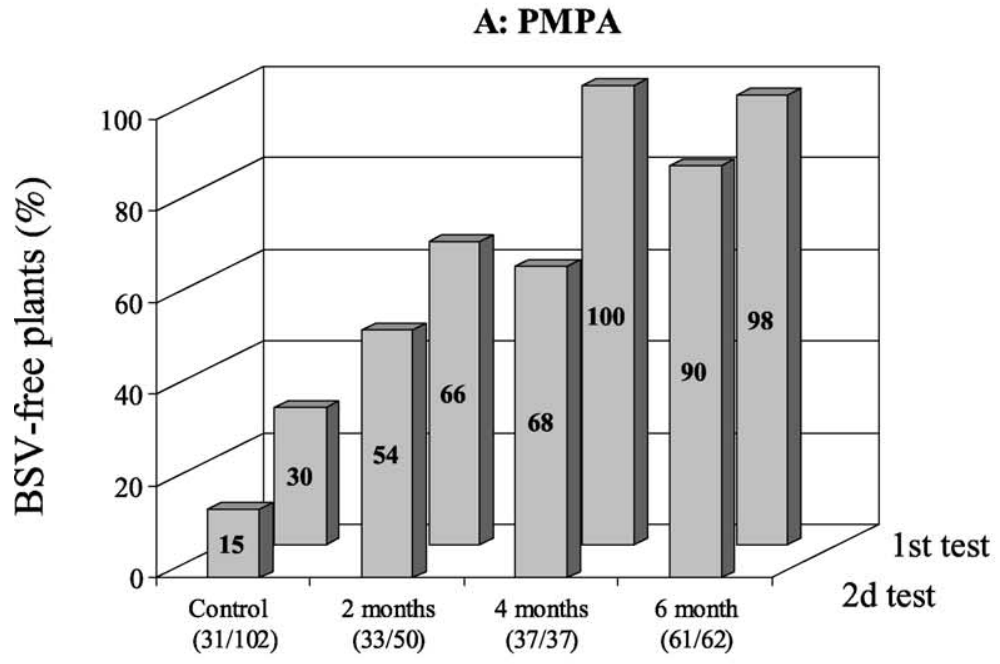

B:PMEA

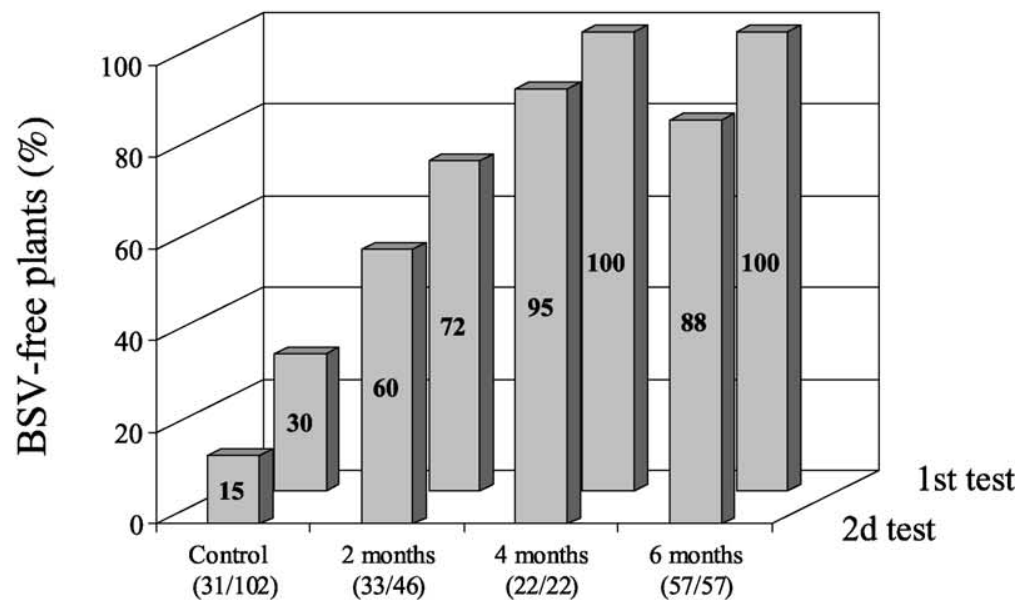

C: PMEDAP

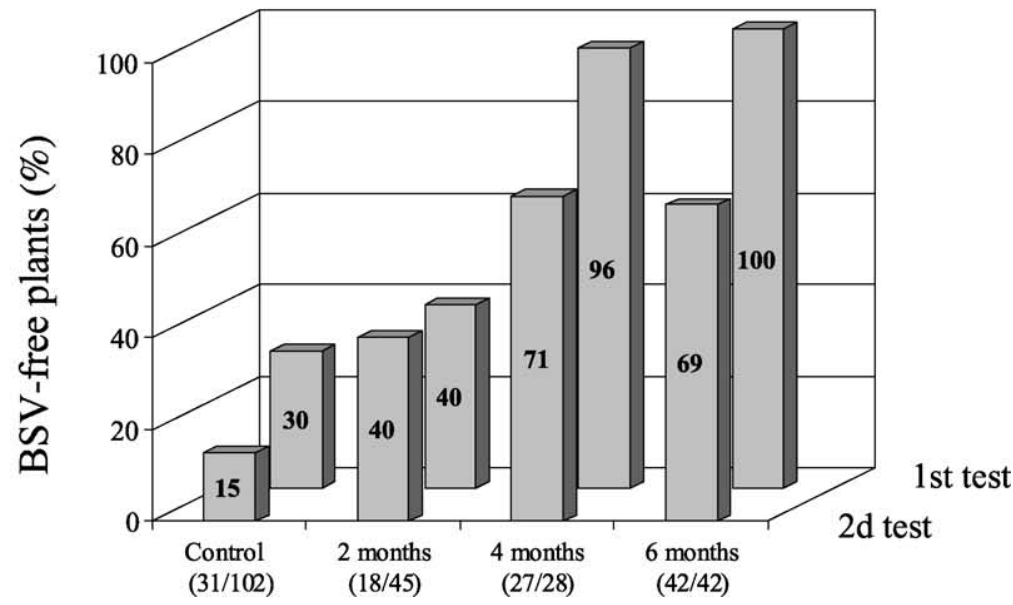

Fig. 3. Eradication rates obtained for plants regenerated from BSV-infected banana meristem clumps (cv. Williams BSJ, ITC.0579, AAA), chopped, mixed and treated for either 2, 4 or 6 months with $10 \mathrm{mg} / \mathrm{l}$ of (A) tenofovir (PMPA), (B) adefovir (PMEA) or (C) PMEDAP. Viral status of plants was assessed by ELISA on in vitro plants (first test) and on in vivo plants (second test) after a 6-months acclimation in the greenhouse. The number in brackets indicate the number of BSV-free plantlets per total number of plantlets after the first test. 
although formal proof is still needed to demonstrate an inhibitory effect of the 5'-diphosphorylated metabolites of PMPA, PMEA and PMEDAP on the (recombinant) enzyme.

An interesting question to address would also be the characteristics of intracellular phosphorylation of the acyclic nucleoside phosphonates in plant cells. Biosynthetic pathways of nucleosides/nucleotides in plant and animal cells are roughly the same. Several enzymes have been reported to be involved in the phosphorylation of adefovir and tenofovir. These include 5-phosphoribosyl-1-pyrophosphate (PRPP) synthetase, AMP(dAMP) kinase and nucleoside diphosphate kinase (Balzarini et al., 1991; Merta et al., 1992). Plants encode enzymes that are homologues to these latter enzymes (www.mips.biochem.mpg.de/projects/plants).

This is to the best of our knowledge the first report of the selective inhibition of the replication of a plant virus by a compound that specifically targets the reverse transcriptase. Tenofovir, adefovir or PMEDAP may prove powerful tools for the eradication of the episomal form of BSV from banana. The distribution of banana plants is greatly hampered by viruses, such as BSV. The production of virus-free planting stocks of these vegetatively propagated plants has been recognised as one of the most important control measures and facilitates the international diffusion of high yielding and newly bred varieties as well as the preservation of banana germplasm. The method reported here may provide a convenient approach towards the production of such virus-free planting stocks. The availability of these compounds may also facilitate the study of the activation of the integrated sequence into the banana genome. Moreover, the results of this report might lead to wider application for the eradication of badnaviruses from other plant species.

\section{Acknowledgements}

The study was performed in the framework of an International Network for the Improvement of Banana and Plantain (INIBAP) project entitled "Development of in vitro culture techniques for virus diseases elimination from Musa" and was largely supported with funding provided by the Directorate General for International Cooperation (DGIC, Belgium). This work is part of the global PROMUSA programme.

\section{References}

Balzarini, J., Hao, Z., Herdewijn, P., Johns, D.G., De Clercq, E., 1991. Intracellular metabolism and mechanism of anti-retrovirus action of 9-(2-phosphonylmethoxy-ethyl)adenine, a potent anti-human immunodeficiency virus compound. Proc. Natl. Acad. Sci. U.S.A. 88, 14991503.

Balzarini, J., Holý, A., Jindrich, J., Naesens, L., Snoeck, R., Schols, D., De Clercq, E., 1993. Differential antiherpesvirus and antiretrovirus effects of the $(S)$ and $(R)$ enantiomers of acyclic nucleoside phosphonates: potent and selective in vitro and in vivo antiretrovirus ac- tivities of (R)-9-(2-phosphonomethoxypropyl)-2,6-diamino-purine. Antimicrob. Agents Chemother. 37, 332-338.

Bouhida, M., Lockhart, B.E.L., Olszewski, N.E., 1993. An analysis of the complete sequence of a sugarcane bacilliform virus genome infectious to banana and rice. J. Gen. Virol. 74, 15-22.

Daniells, J., Jenny, C., Karamura, D., Tomekpe, K., 2001. Williams, cultivated varieties AAA. In: Arnaud, E., Sharrock, S. (Eds.), Musalogue: A Catalogue of Musa Germplasm-Diversity in the Genus Musa. INIBAP, Montpellier, France, p. 67.

Delanoy, M., Jijakli, M.H., Lepoivre, P., 2001. Detection of Banana streak virus (BSV) by IC-PCR-ELOSA. In: Abstracts of Joint Meeting of APS, MSA and SON, Salt Lake City, USA, August 25-29. Phytopathology 91-6 (Suppl.), S22.

Diekmann, M., Putter, C.A.J., 1996. FAO/IPGRI Technical Guidelines for the Safe Movement of Germplasm. No. 15. Musa, 2nd ed. Food and Agricultural Organization of the United Nations, Rome/International Plant Genetic Resources Institute, Rome, 26 pp.

Frison, E.A., Sharrock, S., 1999. The economic, social and nutritional importance of banana in the world, In: Picq, C., Fouré, E., Frison, E.A. (Eds.), Banana and Food Security. INIBAP, Montpellier, France, pp. 21-35.

Geering, A.D.W., Olszwski, N.E., Dahal, G., Thomas, J.E., Lockhart, B.E.L., 2001. Analysis of the distribution and structure of integrated Banana streak virus DNA in a range of Musa cultivars. Mol. Plant Pathol. 2-4, 207-213.

Hagen, L.S., Jacquemond, M., Lepingle, A., Lot, H., Tepfler, M., 1993. Nucleic acid sequence and genomic organization of Cacao swollen shoot virus. Virology 196, 619-628.

Harper, G., Hull, R., 1998. Cloning and sequence analysis of Banana streak virus DNA. Virus Genes 17-3, 1-9.

Harper, G., Osuji, J., Heslop-Harrison, J.S., Hull, R., 1999. Integration of banana streak badnavirus into the Musa genome: molecular and cytogenetic evidence. Virology 255, 207-213.

Hay, J.M., Jones, M.C., Blakebrough, M.L., Dasgupta, I., Davies, J.W., Hull, R., 1991. An analysis of the sequence of an infectious clone of Rice tungro bacilliform virus, a plant pararetrovirus. Nucleic Acids Res. 19, 2615-2621.

Heijtink, R.A., De Wilde, G.A., Kruining, J., Berk, L., Balzarini, J., De Clercq, E., Holý, A., Schalm, S.W., 1993. Inhibitory effect of 9-(2-phosphonylmethoxyethyl)-adenine (PMEA) on human and Duck hepatitis $B$ virus infection. Antivir. Res. 21, 141-153.

Helliot, B., Panis, B., Poumay, Y., Swennen, R., Lepoivre, P., Frison, E., 2002. Cryopreservation for the elimination of Cucumber mosaic or Banana streak viruses from banana (Musa spp.). Plant Cell Rep. 20, $1117-1122$.

Helliot, B., Swennen, R., Poumay, Y., Frison, E., Lepoivre, P., Panis, B., 2003. Ultrastructural changes associated with cryopreservation of banana (Musa spp.) highly proliferating meristems. Plant Cell Rep. 21, 690-698.

LaFleur, D.A., Lockhart, B.E.L., Olszewski, N.E., 1996. Portions of the banana streak badnavirus genome are integrated in the genome of its host Musa. Phytopathology 86, S100-S101.

Lassoudière, A., 1974. La mosaïque dite "à tirets" du bananier "Poyo" en Côte d'Ivoire. Fruits 29, 349-357.

Lockhart, B.E.L., 1986. Purification and serology of a bacilliform virus associated with a streak disease of banana. Phytopathology 76, 995999.

Lockhart, B.E.L., 1990. Evidence for a double-stranded circular DNA genome in a second group of plant viruses. Phytopathology 80-2, 127131.

Lockhart, B.E.L., Jones, D.R., 2000. Banana streak. In: Jones, D.R. (Ed.), Diseases of Banana, Abaca and Enset. CABI Publishing, pp. 263-274.

Lockhart, B.E.L., Olszewski, N.E., 1993. Serological and genomic heterogeneity of banana streak badnavirus: implications for the virus detection in Musa germplasm. In: Ganry, J. (Ed.), Breeding Banana and Plantain for Resistance to Diseases and Pests, Proceedings of the International 
Symposium on Genetic Improvement of Bananas for Resistance to Diseases and Pests. CIRAD, Montpellier, France, pp. 105-113.

Medberry, S.L., Lockhart, B.E.L., Olszewski, N.E., 1990. Properties of Commelina yellow mottle virus's complete DNA sequence, genomic discontinuities and transcript suggest that it is a pararetrovirus. Nucleic Acids Res. 18, 5505-5513.

Merta, A., Vortruba, I., Jindrich, J., Holy, A., Cihlar, T., Rosenberg, I., Otmar, M., Herve, T.Y., 1992. Phosphorylation of 9-(2-phosphonomethoxyethyl)adenine and 9-(S)-(3-hydroxy-2-phosphonomethoxypropyl)adenine by AMP (dAMP) kinase from L1210 cells. Biochem. Pharmacol. 17, 2067-2077.

Murashige, T., Skoog, A., 1962. A revised medium for rapid growth and bioassays with tobacco tissues cultures. Physiol. Plant. 15, 473-497.

Naesens, L., Snoeck, R., Andrei, G., Balzarini, J., Neyts, J., De Clercq, E., 1997. HPMPC (cidofovir), PMEA (adefovir) and related acyclic nucleoside phosphonate analogues: a review of their pharmacology and clinical potential in the treatment of viral infections. Antivir. Chem. Chemother. 8, 1-23.
Ndowora, T.C.R., Lockhart, B.E.L., 2000. Development of a serological assay for detecting serologically diverse Banana streak virus isolates. Acta Hort. 540, 377-388.

Ndowora, T., Dahal, G., LaFleur, D., Harper, G., Hull, R., Olzewski, N.E., Lockhart, B.E.L., 1999. Evidence that badnavirus infection in Musa can originate from integrated pararetroviral sequences. Virology 255, 214-220.

Panis, B., Totté, N., Van Nimmen, K., Withers, L.A., Swennen, R., 1996. Cryopreservation of banana (Musa spp.) meristems cultures after preculture on sucrose. Plant Sci. 21, 95-106.

Ying, C., De Clercq, E., Neyts, J., 2000a. Lamivudine, adefovir and tenofovir exhibit long-lasting anti-hepatitis B virus activity in cell culture. J. Viral Hepat. 7, 79-83.

Ying, C., De Clercq, E., Nicholson, W., Furman, P., Neyts, J., 2000b. Inhibition of the replication of the DNA polymerase M550V mutation variant of human Hepatitis B virus by adefovir, tenofovir, L-FMAU, DAPD, penciclovir and lobucavir. J. Viral Hepat. 7, 161165. 